African Crop Science Journal, Vol. 29, No. 3, pp. 383 - 400

Printed in Uganda. All rights reserved
ISSN 1021-9730/2021 \$4.00

(C) 2021, African Crop Science Society

African Crop Science Journal by African Crop Science Society is licensed under a Creative Commons Attribution 3.0 Uganda License. Based on a work at www.ajol.info/ and www.bioline.org.br/cs DOI: https://dx.doi.org/10.4314/acsj.v29i3.5

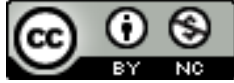

\title{
OCCURRENCE OF RICE YELLOW MOTTLE VIRUS RESISTANCE BREAKING ISOLATES IN LOWLAND CATCHMENT ZONES OF UGANDA
}

\author{
I. RAMATHANI, S.B. MUKASA ${ }^{1}$, T. ALICAI, S. NANYITI and J. LAMO
}

National Crops Resources Research Institute, Namulonge, P. O. Box 7084, Kampala, Uganda

${ }^{1}$ College of Agricultural and Environmental Sciences, Makerere University, P. O. Box 7062,

Kampala, Uganda

Corresponding author: i.ramathani@gmail.com

(Received 23 June 2021; accepted 19 August 2021)

\begin{abstract}
Rice (Oryza spp; $2 \mathrm{n}=24$.) production in Uganda and Africa in general, is seriously threatened by the Rice yellow mottle virus disease (RYMVD), a disease caused by Rice yellow mottle virus (RYMV) within the genus Sobemovirus; family Sobemoviridae. This study investigated the existence and distribution of resistance-breaking RYMV pathotype in the three major lowland rice catchment areas in Uganda. Four known rice accessions resistant to Rice yellow mottle virus (RYMV) namely; Gigante, Tog5672, Tog5674 and Tog5681, carrying resistant allele's rymv1-2, rymv1-4 \& RYMV3, rymv1-5 and rymv1-3, respectively, were tested for their response to different RYMV isolates. The isolates were collected from three major lowland rice catchment areas of Doho, Kibimba, and Olweny in Uganda. Out of 100 leaf samples collected from the field and assayed for RYMV and confirmed to be positive using RT-PCR, 83 isolates induced symptoms on IR64- the RYMV susceptible line. Seventyseven $(92.8 \%)$ isolates were able to overcome resistance in at least one of the four differential rice accessions, as confirmed by the presence of RYMV symptoms; while $6(7.2 \%)$ isolates were asymptomatic. Variation in time (days) for symptom development post-inoculation (dpi) and AUDPC were observed. Symptoms appeared within 5-7 days on IR64; while it took on average 11, 18, 36, and 18 days to appear on Gigante, Tog5672, Tog5674 and Tog5681, respectively. The highest AUDPC was observed on IR64 (254.7); while the lowest was observed on Tog5681 (74.1). Two major patho-groups were observed; those that broke down resistance in Gigante only $(25.3 \%)$ and Gigante \& Tog5672 (33.7\%). Five isolates from Doho (Budaka \& Bugiri districts) and Kibimba (Butaleja district) catchment areas broke down RYMV resistance in three accessions i.e. (Tog5681, Gigante \& Tog5672) and (Tog5674, Gigante \& Tog5672), respectively. Resistance breaking isolates were confirmed in all the three sampled catchment zones, however, Doho and Kibimba had some unique isolates that broke down resistance in accessions carrying resistance allele rymv 1-3 and rymv1-5 in addition to rymv1-2. Results from this study showed that RYMV isolates in Uganda can break down resistance conferred by the rymv1-2 resistance gene allele. However, accessions Tog5681 and Tog5674 seem to hold stable RYMV resistance and, thus are recommended for RYMV breeding.
\end{abstract}

Key Words: Accession, breakdown, catchment,Oryza sativa, resistance 
La production de riz (Oryza spp ; 2n=24.) en Ouganda et en Afrique en général, est sérieusement menacée par la maladie du virus de la marbrure jaune du riz (RYMVD), une maladie causée par le virus de la marbrure jaune du riz (RYMV) du genre Sobemovirus; famille des Sobemoviridae. Cette étude a examiné l'existence et la distribution du pathotype RYMV qui brise la résistance dans les trois principaux bassins versants de riz de plaine en Ouganda. Les quatre accessions de riz connues résistantes au virus de la panachure jaune du riz (RYMV, Rice yellow mottle virus) à savoir; Gigante, Tog5672, Tog5674 et Tog5681, portant respectivement les allèles résistants rymv1-2, rymv1-4 \& RYMV3, rymv15 et rymv1-3, ont été testés pour leur réponse à différents isolats de RYMV. Les isolats ont été collectés dans les trois principaux bassins versants du riz de plaine de Doho, Kibimba et Olweny en Ouganda. Sur les 100 échantillons des feuilles prélevés sur le terrain et testés pour le RYMV et confirmés positifs par RT-PCR, 83 isolats ont induit des symptômes sur IR64, la lignée sensible au RYMV. Les soixantedix-sept $(92,8 \%)$ isolats ont réussi à surmonter la résistance dans au moins une des quatre accessions du riz différentielles, comme le confirme la présence des symptômes du RYMV ; tandis que $6(7,2 \%)$ isolats étaient asymptomatiques. Une variation dans le temps (jours) pour le développement des symptômes après l'inoculation (dpi, development post-inoculation) et l'AUDPC a été observée. Les symptômes sont apparus dans les 5 à 7 jours sur IR64 ; alors qu'il a fallu en moyenne 11, 18, 36 et 18 jours pour apparaître sur Gigante, Tog5672, $\operatorname{Tog} 5674$ et Tog5681, respectivement. L'AUDPC le plus élevé a été observé sur IR64 (254,7); tandis que l'AUDPC le plus bas a été observé sur Tog5681 $(74,1)$. Deux patho-groupes principaux ont été observés; ceux qui ont brisé la résistance dans les Gigante uniquement $(25,3 \%)$ et Gigante \& Tog5672 (33,7\%). Les cinq isolats des bassins versants de Doho (districts de Budaka et Bugiri) et de Kibimba (district de Butaleja) ont brisé la résistance au RYMV dans trois accessions, à savoir (Tog5681, Gigante et Tog5672) et (Tog5674, Gigante et Tog5672), respectivement. Des isolats brisant la résistance ont été confirmés dans les trois zones de captage échantillonnées, cependant, Doho et Kibimba avaient des isolats uniques qui brisaient la résistance dans des accessions portant les allèles de résistance rymv1-3 et rymv1-5 en plus de rymv1-2. Les résultats de cette étude ont montré que les isolats de RYMV en Ouganda peuvent briser la résistance conférée par l'allèle du gène de résistance rymv1-2. Cependant, les accessions Tog5681 et Tog5674 semblent détenir une résistance stable au RYMV et sont donc recommandées pour la sélection du RYMV.

Mots Clés: Accession, brisure, bassin versant, Oryza sativa, résistance

\section{INTRODUCTION}

Rice (Oryza spp; $2 \mathrm{n}=24$.) production in Uganda and Africa, in general, is seriously threatened by the Rice yellow mottle virus disease (RYMVD), a disease caused by Rice yellow mottle virus (RYMV) within the genus Sobemovirus; family Sobemoviridae (Kouassi et al., 2005). Rice yellow mottle virus was first reported in Uganda, in a field growing paddy rice north-east of Lake Victoria close to the Nile river in 2000 (Pinel-Galzi et al., 2006). Under natural conditions, the known vectors for RYMV transmission are chrysomelid beetles (Order Coleoptera: Chrysomelidae) (Koudamiloro et al., 2015); however, mammals like cows, rats, and donkeys have been implicated in the transmission process as well (Sarra and Peters, 2003). Furthermore, the virus is known to be spread through the action of wind, farming equipment and contaminated human hands (Sarra et al., 2003, 2004).

Vector control to prevent virus spread is hampered by the complexity of the virus's epidemiology, thus the need to develop resistant accessions. In Uganda, most available rice accessions, especially those of the Oryza 
sativa indicas species, are susceptible to RYMV (Bouake189, BG90-2, and IR64), and they may suffer from 25 to $100 \%$ yield losses (N'Guessan et al., 2001). However, the rice (O. sativa) accession Gigante (rymv1-2) and the African rice $(O$. glaberrima) accessions Tog5681 (rymv1-3), Tog5672 (rymv1-4, RYMV3), and Tog5674 (rymv1-5) are reported to be highly resistant to RYMV (Ndjiondjop et al., 1999; Thiémélé et al., 2010).

In Gigante, Tog5674 and Tog5681, RYMV resistance allele behaves as a monogenic recessive genetic trait and is associated with lack of symptom development and blockage of virus movement, however, in Tog5307 resistance is under the control of a dominant single gene (RYMV3) also found in Tog5672 (Ndjiondjop et al., 2001; Pidon et al., 2017, 2020). Two resistance genes i.e. RYMV2 and RYMV3, have been mapped in $O$. glaberrima species. RYMV2-mediated resistance is associated with a $1 \mathrm{bp}$ deletion, leading to a null allele of a homolog of the Arabidopsis constitutive expression of pathogenesis-related protein-5 (CPR5) nucleoporin gene, in both a bi-parental mapping population and a collection of $O$. glaberrima accessions. The diversity of RYMV resistance in $O$. glaberrima suggests that these traits can be employed in the rice breeding program (Pidon et al., 2020).

The emergence of resistance-breaking isolates (Amancho et al., 2009) is a matter of concern. The existence of these kinds of RYMV isolates has been observed in Uganda, with the breakdown of resistance in Gigante (Ochola and Tusiime, 2011). Therefore, the deployment of resistant accessions in a ricegrowing environment requires a good knowledge of the virus diversity. This study investigated the existence and distribution of resistance-breaking RYMV pathotype in the three major lowland rice catchment areas in Uganda.

\section{MATERIALS AND METHODS}

Study area. This study was conducted in three major rice lowland catchment areas of
Doho, Kibimba, and Olweny in Uganda, from January to March 2020. Doho rice scheme is located in Butaleja in Eastern Uganda, at Longitude $34^{\circ} 02^{\prime}$ East of the Greenwich and Latitude $0^{\circ} 56^{\prime}$ North of the Equator on the right bank of Manafwa River. Doho catchment area is located within the Lake Kyoga basin and covers an area of $494.2 \mathrm{~km}^{2}$ (Bwambale et al., 2019). Doho catchment zones covers about 14 districts namely Budaka, Kibuuka, Bukedea, Busembatia, Kumi, Kaliro, Luuka, Soroti, Kamuli, Mbale, Ngora, Butaleja, Iganga and Pallisa. These districts are served by two rivers (River Manafwa and Mpologama) and Lake Kyoga. The catchment has over 2500 acres (1000 Ha) of irrigated land and over 10,000 small-holder farmers are engaged in rice production. Kibimba catchment is located at latitude $0^{\circ} 32^{\prime} 2462 \mathrm{~N}$ and longitude $33^{\circ} 52^{\prime} 9350 \mathrm{E}$, in Bugiri district. The total area under the catchment is 14,000 hectares and approximately 4,000 hectares are under rice production (Zeemeijer, 2012; Birdlife International, 2021). This catchment is drained by the Kibimba River and covers other districts including Namutumba, Mayuge, Tororo, and Bugiri. Olweny catchment zone is located within the Olweny swamps (Lango region) in Lira district. It at longitude $33^{\circ} 01^{\prime}$ East of the Greenwich and Latitude $2^{\circ} 00^{\prime}$ North of the Equator in Agwata sub-county. Olweny has a potential irrigable area of 6,039 ha and 800 ha is being used for rice production by 4,500 farmers (World Bank, 2020).

Plants, virus sources and propagation. The plant accessions used in this study included four RYMV resistant accessions, Gigante, Tog5674, Tog5672, and Tog5681, which are currently used as donor parents for introgression of RYMV resistance genes/alleles in farmer preferred rice accessions in the breeding programme at the National Crops Resources Research Institute (NaCRRI), Namulonge, Wakiso district in Uganda. IR64 accession was included as the RYMV susceptible local control (Table 1). The above accessions were provided by Dr. Drissa from 
TABLE 1. Rice yellow mottle virus differential lines used in the assessment of their reactions to the $R Y M V$ isolates collected from lowland rice catchment areas of Uganda

\begin{tabular}{lllll}
\hline Rice accessions & Rice species & Origin & $\begin{array}{l}\text { RYM disease } \\
\text { attribute }\end{array}$ & $\begin{array}{l}\text { RYMV resistance genes/ } \\
\text { alleles present in accession }\end{array}$ \\
\hline Bouake189 & O. sativa & CNRA & Susceptible & - \\
IR64 & O. sativa & AfricaRice & Susceptible & rymv 1-1 \\
Gigante & O. sativa & AfricaRice & Resistant & rymv 1-2 \\
Tog5681 & O. glaberrima & AfricaRice & Resistant & rymv 1-3 \\
Tog5674 & O. glaberrima & AfricaRice & Resistant & rymv 1-5 \\
Tog5672 & O. glaberrima & AfricaRice & Resistant & rymv 1-4, RYMV3
\end{tabular}

- = No resistance gene; CNRA = Centre National de Recherche Agronomique

AfricaRice, Benin formerly WARDA (West Africa Rice Development Agency).

A total of $100 \mathrm{RYMV}$ isolates were collected from rice fields in the three catchment zones of Doho rice irrigation scheme (Butaleja, Kibuuka, Bukedea, Busembatia, Kumi, Kaliro, Luuka, Soroti, Kamuli Mbale, Ngora, Budaka, Kamuli, Iganga and Pallisa districts), Olweny swamp rice irrigation scheme (Lira, Apac, Koboko and Kolo districts) and Kibimba rice irrigation scheme (Mayuge, Bugiri, Busia, Tororo, and Namutumba districts).

To obtain sufficient viral source material, RYMV isolates collected from the field were initially mechanically inoculated and propagated on the susceptible accession Bouake189, before inoculation on the differential accessions. Leaf samples were ground in an inoculation buffer $(100 \mathrm{mM}$

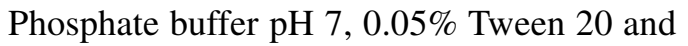
$2 \%$ PVP $24 \mathrm{kD}$ : $10 \mathrm{ml}$ per g leaf sample), using sterile mortars and pestles. Carborundum (600 mesh; $5 \mathrm{mg} \mathrm{ml}^{-1}$ ) was added as an abrasive to the extracts, which were subsequently rubbed onto the leaves of 2 -week-old seedlings ( 3 plants).

Leaves were collected from infected plants at 14 days post-inoculation and used as an inoculum source for resistance evaluation tests. The number of leaf samples used for the initial inoculation was varying and this did not affect the inoculum load as it was reported that
RYMV accumulates to the similar extent in the susceptible cultivar (Bouake189) whatever pathotype is being used for inoculation. The trial was repeated twice for consistency of results.

Evaluation of resistance to RYMV. An experiment was set up in an insect-proof greenhouse at 25 to $30{ }^{\circ} \mathrm{C}$ and 80 to $90 \%$ relative humidity. Two trials were set up i.e. Trial one -from January to June and Trial 2 from June to September, 2020. Seeds of RYMV resistant accessions: Gigante, Tog5681, Tog5674, Tog5672, and the susceptible standard IR64 were sown in 5-liter pots using sterilised forest soil. Mechanical inoculation was carried out on 5 plants per isolates per accession, three weeks post-germination, as described by (Amancho et al., 2009). The inoculated plants were monitored once a week, until the flowering stage for the occurrence of RYMV symptoms. Thereafter, disease severity was scored using a 1 (no symptoms) to 9 (severe symptoms) scale (IRRI, 1988). The severity data were used to calculate the Area Under disease progress curve (AUDPC) based on the model proposed by Campbell and Madden (1990) as below.

$$
\mathrm{AUDPC}=\sum_{i=1}^{n}\left[\left(Y_{i+1}+Y_{i}\right)\right]\left[\left(t_{i+1}-t_{i}\right)\right]
$$


Where:

$\mathrm{n}=$ number of dates on which RYMV was recorded,

$\mathrm{Yi}=$ disease severity at the date I,

$\mathrm{ti}=$ number of days after the first observation of RYMV symptoms on assessment date i.

Confirmation of RYMV. All isolates that showed RYMV symptoms on Bouake 189 were tested by RT-PCR to confirm the virus presence. Total RNA was extracted from frozen infected rice leaves (picked from symptomatic leaves, except the inoculated leaf) using the RNeasy Plant Mini Kit (Qiagen), following the manufacturer's instructions. One hundred milligrams of plant tissue frozen in liquid nitrogen was disrupted using a sterile mortar and pestle. The disrupted tissue powder was placed into an RNase-free, liquid-nitrogencooled, $2 \mathrm{ml}$ micro-centrifuge tube, followed by the addition of $450 \mu \mathrm{l}$ Buffer RLT. The mixture was vortexed vigorously for about 10 seconds then transferred into a QIA shredder spin column (lilac) placed in a $2 \mathrm{ml}$ collection tube. The tube was centrifuged for two minutes at full speed (13,000 revolutions/ minute).

The supernatant was transferred into a new micro-centrifuge tube without disturbing the cell-debris pellet. After 0.5 volume of ethanol $(99 \%)$ was added to the cleared lysate, and mix immediately by pipetting. The mixture was then transferred to an RNeasy Mini spin column (pink) in a two ml collection tube. The lid was closed and then centrifuged for $15 \mathrm{~s}$ at $>8000 \mathrm{x} \mathrm{g}(>10,000 \mathrm{rpm})$. The flowthrough was discarded, followed by the addition of $700 \mu \mathrm{l}$ of Buffer RW1 to the RNeasy spin column then centrifuged again for $15 \mathrm{sec}$ at $>8000 \mathrm{x}$. The flow-through was treated as before, followed by the addition of $500 \mu \mathrm{l}$ Buffer RPE to the RNeasy spin column then centrifuged for $15 \mathrm{sec}$ at $>8000$ $\mathrm{x} g$. The flow-through was discarded once more, followed by the addition of $500 \mu \mathrm{l}$
Buffer RPE to the RNeasy spin column then centrifuged for $2 \mathrm{~min}$ at $>8000 \mathrm{x} \mathrm{g}$.

Finally, the RNeasy spin column was placed in a new $1.5 \mathrm{ml}$ collection tube and $50 \mu \mathrm{l}$ RNase-free water was added directly to the spin column membrane then centrifuged for 1 min at $>8000 \times \mathrm{g}$ to elute the RNA. The last step was repeated once more to elute more RNA from the column membrane. The quality and concentration of extracted RNA were determined using a NanoDrop spectrophotometer (Thermo Fisher Scientific, USA). Samples with a 260/280 ratio of $>2.0$ were considered as having good RNA. RNA quality was further confirmed by visualising samples using TAE/Formamide agarose gel electrophoresis as described by Masek et al. (2005) and only those showing no genomic DNA contamination or RNA degradation were selected for running RT-PCR.

The RNA extracted was converted into cDNA using the Luna Script cDNA kit (SuperMix $2.0 \mu \mathrm{l}$, Nuclease free water $7.5 \mu \mathrm{l}$ and Total RNA $1.0 \mu \mathrm{l}$ ). The mixture was incubated at $25^{\circ} \mathrm{C}$ for 2 minutes, followed by $55^{\circ} \mathrm{C}$ for 10 minutes. The reaction was then terminated at $95{ }^{\circ} \mathrm{C}$ for 1 minute. PCR was performed in a reaction volume of $50 \mathrm{uL}$ using the one Taq quick-load master mix (Premix $25.0 \mu \mathrm{l}$, Forward and Reverse primers (10 pmoles) and water). The primers used were degenerate primers designed to cover the entire coat protein of RYMV CP FP1 (5' TCTCCCA CAAAGATRGCCAGGAAGGGCAAGAAA3') (the nucleotide position 3433 to 3465 ) and RYMV CP RP1 (5'RWCCGGYTCACGTAT TGAGTGTTGGATCAAC-3') (position 4141 to 4171$), 1.0 \mu \mathrm{l}$, Nuclease free water $1.0 \mu \mathrm{l}$ and cDNA template $2.0 \mu \mathrm{l}$ ).

The mixture was then placed within a thermocycler (Eppendorf Master cycler X50s 96-well Silver Block, Thermocycler, Model 6311000010) with conditions: initial denaturation $94{ }^{\circ} \mathrm{C}$ for 5 minutes then 30 cycles of $94{ }^{\circ} \mathrm{C}$ for 30 seconds, $67.2{ }^{\circ} \mathrm{C}$ for 30 seconds, $72{ }^{\circ} \mathrm{C}$ for 30 seconds, final extension at $72{ }^{\circ} \mathrm{C}$ for 5 minutes then hold at 
$4{ }^{\circ} \mathrm{C}$. The PCR product was run on a $1 \% \mathrm{TAE}$ agarose gel stained with EtBr for UV visualization. A 738 bp PCR product was confirmed using a $1 \mathrm{~Kb}$ ladder.

Data analysis. The severity data were tested for homogeneity before being used to generate the AUPDC values. The AUDPC value for the different accessions was subjected to analysis of variance (ANOVA) and means separated using Turkey's simultaneous tests for unbalanced data at the $95 \%$ confidence interval (Steel et al., 1997). All statistical analyses were performed using GenStat 7 version 3.2, 2007 (Lawes Agricultural Trust: Rothamsted Experimental Station, UK).

\section{RESULTS}

Symptom expression. From the three catchment zones surveyed, 100 RYMV symptomatic samples were collected and propagated onto Bouake189 at NaCRRI, before evaluating them on the selected differential lines. Only 83 samples showed RYMV symptoms on Bouake189 and were confirmed RYMV positive by RT-PCR (Fig. 1) and then tested on the differential lines. All of the 83 RYMV isolates showed visible symptoms on IR64 (a highly RYMV susceptible line). Of these, $92.8 \%$ (77 isolates) induced clearly visible symptoms on Gigante, 46.99\% (39 isolates) on Tog5672, 4.82\% (4 isolates) on Tog5674 and $2.41 \%$ (2 isolates) on Tog5681 (Table 2). Average severity scores were high (7-9) in IR64 and lower (3 to 5) among the resistant accessions (Tog5672, Tog5674 and Tog5681); however, RYMV symptoms were more discernible in Gigante than in Tog5681. RYMV \% incidence ranged from 25 to $50 \%$ in Gigante or Tog5674, whereas plants from the susceptible check IR64 showed infection rates equal to $100 \%$.

Time for symptom expression. All the 83 isolates induced symptoms on IR64 within 57 days post-inoculation (dpi); however, symptom expression delayed on Gigante, Tog5672, Tog5674, and Tog5681 at averages of $11,18,36$, and $18 \mathrm{dpi}$, respectively. Symptoms appeared much later on Tog5674, compared to other resistant accessions (Fig. 2). Symptoms expressions were more discernible among Gigante and IR64 plants

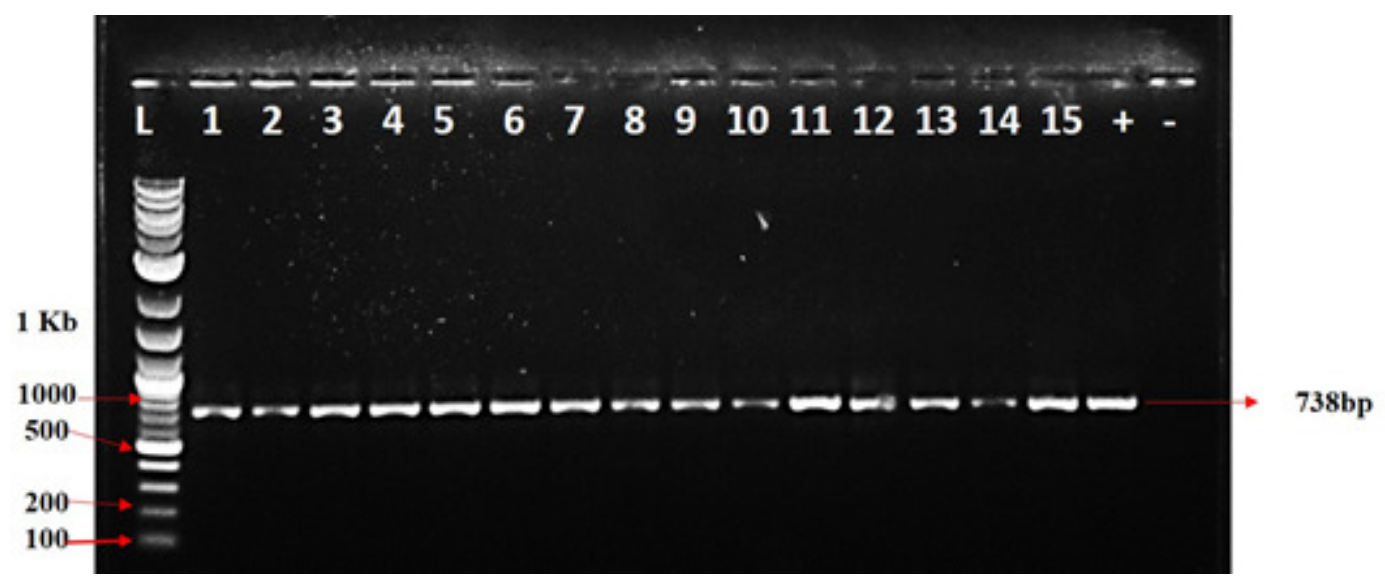

Figure 1. PCR amplicons of Rice yellow mottle virus derived by amplification using degenerate primers ( $R Y M V$ CP FP1 and $R Y M V$ CP RP1designed to cover the entire $R Y M V$ coat. Lane descriptors 1 1-5 Doho catchment (1-Budaka, 2-Kibuuku, 3-Bukedea, 4-Busembatia, 5-Kumi), Kibimba catchment (6-Namutumba, 7-Mayuge, 8-Tororo, 9-Bugiri, 10- Busia) and Olweny catchment (11-Koboko, 12Apac, 13-Lira, 14-Olweny, 15-Kole) + and - positive and negative samples at NaCRRI, Namulonge, Wakiso, L- $1 \mathrm{~Kb}$ ladder. 
TABLE 2. Distribution of resistance breaking $R Y M V$ isolates in sampled localities

\begin{tabular}{|c|c|c|c|c|c|c|c|c|}
\hline Catchment areas & $\begin{array}{l}\text { District } \\
\text { sampled }\end{array}$ & $\begin{array}{c}\text { Number of } \\
\text { samples collected }\end{array}$ & $\begin{array}{l}\text { IR64 } \\
\text { rymv1-1 }\end{array}$ & $\begin{array}{l}\text { Gigante } \\
\text { rymv 1-2 }\end{array}$ & $\begin{array}{l}\text { Tog5681 } \\
\text { rymv 1-3 }\end{array}$ & $\begin{array}{l}\text { Tog5 } 5674 \\
\text { rymv 1-5 }\end{array}$ & $\begin{array}{l}\text { Tog5672 } \\
\text { rymv 1-4, RYMV } 3\end{array}$ & Avirulent isolates \\
\hline & & & --- & $---s$ & iptomatic (V & dent) - - & ----- & Symptomless \\
\hline Doho & Budaka & 6 & 6 & 6 & 2 & 0 & 5 & 0 \\
\hline Doho & Kibuuka & 4 & 4 & 4 & 0 & 0 & 4 & 0 \\
\hline Doho & Bukedea & 5 & 5 & 4 & 0 & 0 & 4 & 1 \\
\hline Doho & Busembatia & 3 & 3 & 3 & 0 & 0 & 2 & 0 \\
\hline Doho & Kumi & 4 & 4 & 3 & 0 & 0 & 3 & 1 \\
\hline Doho & Kaliro & 4 & 4 & 4 & 0 & 0 & 3 & 0 \\
\hline Doho & Luuka & 4 & 4 & 4 & 0 & 0 & 3 & 0 \\
\hline Doho & Soroti & 1 & 1 & 0 & 0 & 0 & 1 & 0 \\
\hline Doho & Kamuli & 5 & 5 & 4 & 0 & 0 & 4 & 1 \\
\hline Doho & Mbale & 1 & 1 & 0 & 0 & 0 & 1 & 0 \\
\hline Doho & Ngora & 2 & 2 & 2 & 0 & 0 & 0 & 0 \\
\hline Doho & Butaleja & 11 & 11 & 11 & 0 & 1 & 2 & 0 \\
\hline Doho & Iganga & 6 & 6 & 6 & 0 & 0 & 3 & 0 \\
\hline Doho & Pallisa & 1 & 1 & 1 & 0 & 0 & 0 & 0 \\
\hline Kibimba & Namutumba & 5 & 5 & 5 & 0 & 0 & 0 & 0 \\
\hline Kibimba & Mayuge & 1 & 1 & 1 & 0 & 0 & 1 & 0 \\
\hline Kibimba & Kibimba & 1 & 1 & 1 & 0 & 0 & 0 & 0 \\
\hline Kibimba & Tororo & 3 & 3 & 3 & 0 & 0 & 0 & 0 \\
\hline Kibimba & Busia & 1 & 1 & 1 & 0 & 0 & 0 & 0 \\
\hline Kibimba & Bugiri & 3 & 3 & 3 & 0 & 2 & 2 & 0 \\
\hline Olweny & Koboko & 1 & 1 & 1 & 0 & 0 & 1 & 0 \\
\hline Olweny & Apac & 3 & 3 & 3 & 0 & 0 & 0 & 0 \\
\hline Olweny & Lira & 3 & 3 & 3 & 0 & 0 & 0 & 0 \\
\hline Olweny & Olweny & 2 & 2 & 1 & 0 & 0 & 0 & 1 \\
\hline \multirow[t]{3}{*}{ Olweny } & Kole & 3 & 3 & 3 & 0 & 1 & 0 & 0 \\
\hline & Total & 83 & 83 & 77 & 2 & 4 & 39 & 4 \\
\hline & $\%$ & 100 & 100 & 92.8 & 2.4 & 4.8 & 47 & 4.9 \\
\hline
\end{tabular}




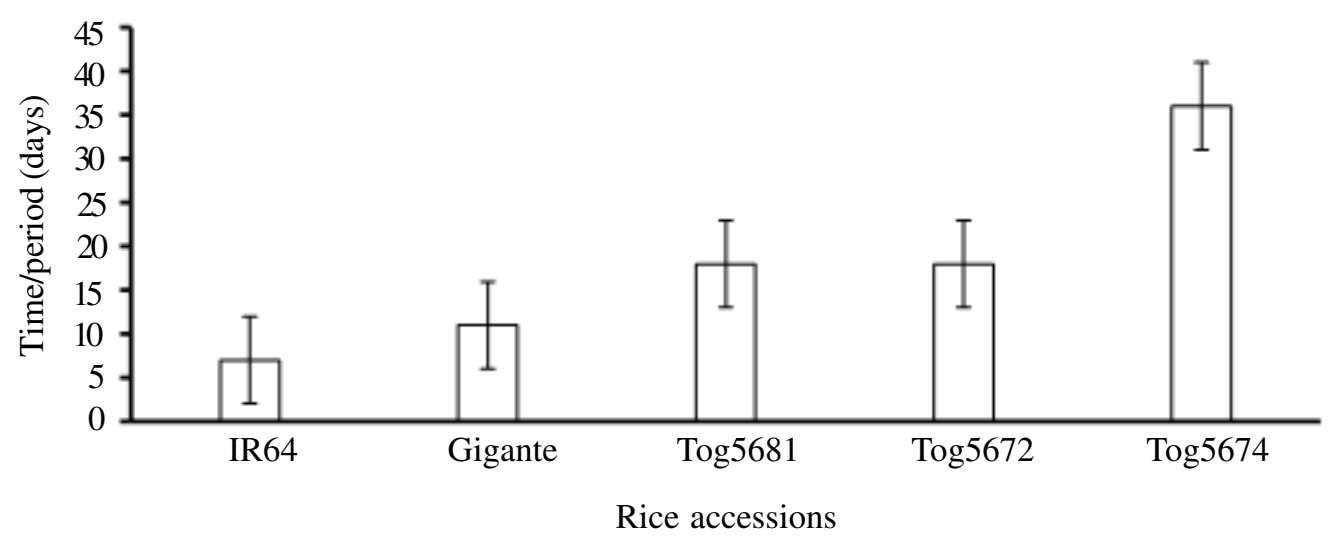

Figure 2. Effect of different $R Y M V$ resistance alleles/genes on time/duration for rice yellow mottle virus disease symptom expression.

than the rest of the tested accessions. IR64 RYMV infected plants died 21dpi and Gigante 35 dpi; however, for Tog5681 and Tog5674 inoculated plants continued to grow and reached maturity. These observations indicate that the RYMV symptom onset period was 5$7 \mathrm{dpi}$ for susceptible accessions (IR64), 7-14 dpi for the partially resistant accession (Gigante) and 18-36 dpi for the highly resistant accessions (Tog5672, Tog5674, and $\operatorname{Tog} 5681)$.

Area under Disease Progress Curve (AUDPC). There were significant differences $(\mathrm{P}<0.05)$ in the AUDPC values among the RYMV isolates and differential lines (Fig. 3). Among the 83 isolates, the AUDPC range for the different differential lines were: 334.5 203.5 for IR64, 334.5-115.5 for Gigante, 150.5-58.5 for $\operatorname{Tog} 5674,182.5-45.5$ for Tog5672 and 270.5-43.5 for Tog5681. The average AUDPC among the samples that induced RYMV symptoms were 254.7 for IR64, 198.0 for Gigante, 95.2 for Tog5674, 135.6 for Tog5672 and 74.1 for Tog5681. These values indicate that IR64 was highly susceptible, Gigante and Tog5672 were moderately resistant, Tog5674 and Tog5681 are resistant to RYMV (Fig. 3).
Prevalence of virus pathotypes. The 83 virus isolates that induced symptoms in the highly resistant rice accessions were divided into six groups (Table 3). The majority of the isolates fell into two major groups. Isolates of the first group (21 isolates) induced symptoms in Gigante only. In the second group of isolates (28 isolates), symptoms were induced in Gigante and Tog5672 only. Five isolates from Doho (Budaka \& Butaleja) and Kibimba (Bugiri) catchment zones broke down resistance in three accessions, i.e. (Tog5681, Gigante, and Tog5672) and (Tog5674, Gigante and Tog5672), respectively. No single isolate was found to induce symptoms in accession Tog5681 only and Tog5674 only (Table 3 ).

RYMV symptomatic versus asymptomatic infection. From the screening trial of the RYMV isolates. Two major categories were identified from the set of 83 symptomatic samples propagated on the susceptible Bouake189. One category comprised of isolates that did not infect the high resistant accessions and these were referred to as avirulent (4 isolates). The second category comprised of the majority of the isolates (79 isolates), and these were able to infect and cause symptoms on the RYMV resistant 


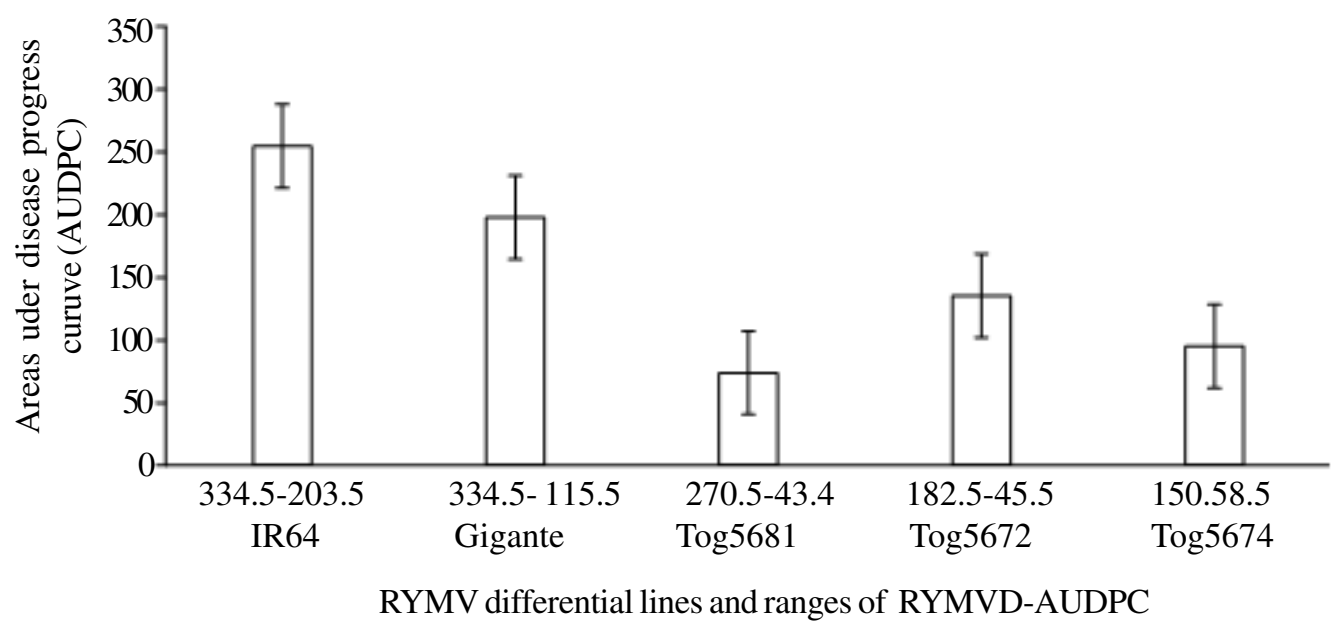

Figure 3. Average Area under disease progress curve among the RYMV isolates that induce symptoms among the respective differential lines.

accessions and thus were termed virulent. The proportion of isolates that were able to breakdown the resistance in Gigante, Tog5681, Tog5674 and Tog5672 were different. The majority of isolates $(92.8 \%)$ infected Gigante an O.sativa line as compared to the O.glaberrima lines (Tog5681, Tog5674, and Tog5672). Furthermore, the majority of the isolates were symptomless on Tog5681 and Tog5674, as compared to Tog5672 and Gigante (Fig. 5).

Resistance breaking isolates distribution. High resistance-breaking isolates were confirmed throughout the three major lowland rice catchment areas with the frequency of occurrence varying from one catchment to another (Figs. 4 and 5). The highest proportion was found in the Doho catchment area, while the lowest was in the Olweny catchment zone. High resistance isolates derived from the rymv1-2 allele occurred more frequently across the three catchment areas; followed by those derived from rymv1-4, RYMV3, and rymv1-5. Isolates breaking resistance for rymv1-3 alleles were found only in Doho catchment area; while isolates breaking down resistance for allele rymv $1-3$ and rymv $1-5$ were less frequent and occurred only in a few sampling sites of Doho ( Budaka, Butaleja), Kibimba (Bugiri) and Olweny (Kole). The majority of the isolates were able to breakdown resistance for only Gigante; while four isolates: two from Kibimba (Bugiri) and two from Doho (Budaka) catchment areas were able to break down resistance among three resistant accessions (Fig. 6).

\section{DISCUSSION}

Deployment of plant resistant varieties is the most appropriate and feasible way to deal with plant viruses. Different breeding programmes have focused on generating virus resistant lines in major crops like rice, cassava, beans (Kreuze and Valkonen, 2017). A number of different disease resistant genes and alleles are targeted and transformed into these crop varieties. For rice, four lines Gigante, Tog5672, Tog5674 and Tog5681, carrying resistant allele's rymv1-2, rymv1-4 \& RYMV3, rymv15 and rymv1-3, respectively, have been reported to be resistant to RYMV (Odongo et al., 2021). However, breeders usually encounter a challenge of breakdown in resistance when they use major resistance genes (Lecoq et al., 2004; Odongo et al., 2021). The reasons for breaking down of the resistance can be 
TABLE 3. Grouping of RYMV isolates based on the nature of resistance break down categories

\begin{tabular}{|c|c|c|c|c|c|}
\hline Accession/genes/Alleles & No. of & No. of alleles & Number of isolates & isolates & $\%$ \\
\hline Gigante (rymv 1-2) & 1 & 1 & $\begin{array}{l}\text { Ngora (2), Pallisa (1), Namutumba (5), Kibimba (1), } \\
\text { Tororo (1), Busia (1), Apac (3), Lira (3), Olweny (2) }\end{array}$ & 21 & 25.3 \\
\hline Tog5672 (rymv 1-4, RYMV3) & 2 & 2 & Soroti (1) and Mbale (1) & 2 & 2.4 \\
\hline Tog5674 (rymvl-5) & 1 & 1 & & 0 & 0 \\
\hline Tog5681(rymv 1-3) & 1 & 1 & & 0 & 0 \\
\hline Gigante +Tog5681 & 1 & 2 & & 0 & 0 \\
\hline Gigante+Tog5674 & 1 & 2 & Kole (1) & 1 & 1.2 \\
\hline Gigante+Tog5672 & 2 & 3 & $\begin{array}{l}\text { Kibuuka (4), Bukedea (4), Busembatia (2), Kumi (3), } \\
\text { Kaliro (3), Luuka (3), Kamuli (4), Iganga (3), } \\
\text { Mayuge (1) Koboko (1) }\end{array}$ & 28 & 33.7 \\
\hline $\operatorname{Tog} 5681+\operatorname{Tog} 5672$ & 2 & 3 & & 0 & 0 \\
\hline $\operatorname{Tog} 5681+\operatorname{Tog} 5674$ & 1 & 2 & & 0 & 0 \\
\hline Gigante+Tog5681+Tog5672 & 2 & 4 & Budaka (2) & 2 & 2.4 \\
\hline Gigante $+\operatorname{Tog} 5681+\operatorname{Tog} 5674$ & 1 & 3 & & 0 & 0 \\
\hline Gigante $+\operatorname{Tog} 5674+\operatorname{Tog} 5672$ & 2 & 4 & Butaleja (1), Bugiri (2) & 3 & 3.6 \\
\hline $\operatorname{Tog} 5674+\operatorname{Tog} 5672+\operatorname{Tog} 5681$ & 2 & 4 & & 0 & 0 \\
\hline Gigante + Tog5674+Tog5672+Tog5 5681 & 2 & 5 & & 0 & 0 \\
\hline
\end{tabular}




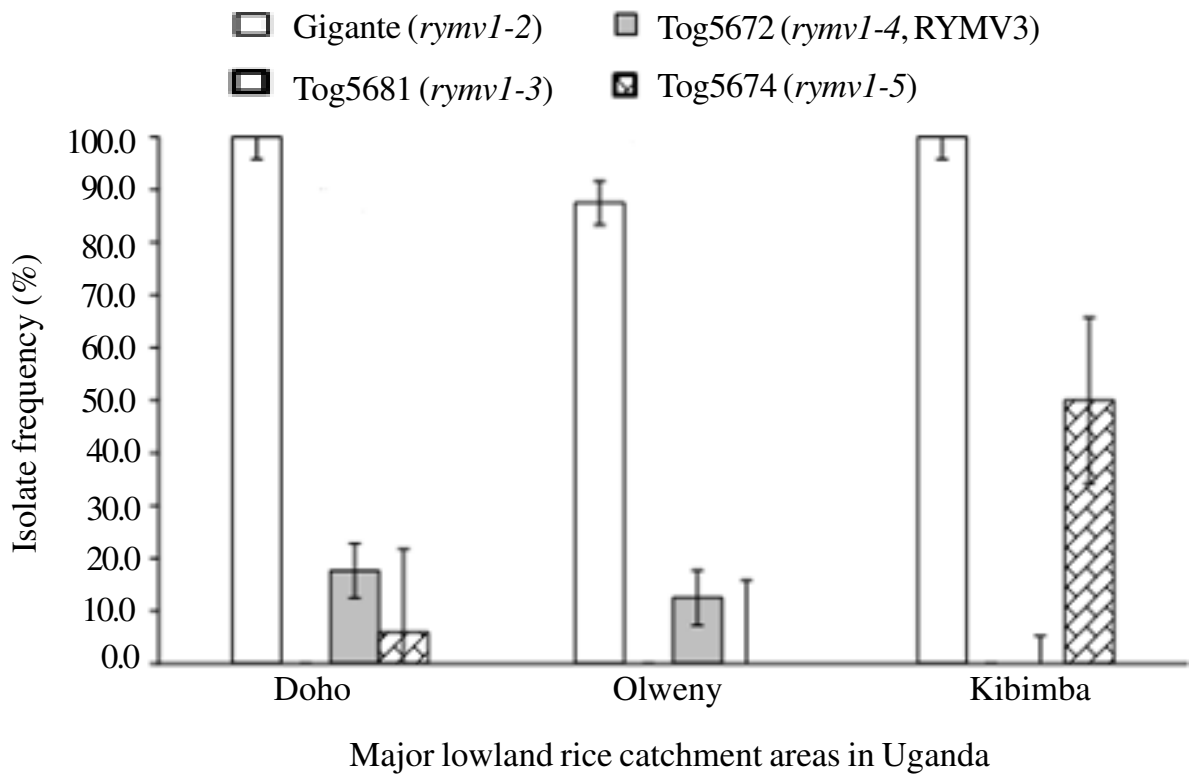

Figure 4. The frequency of occurrence of high resistance-breaking isolates of Rice Yellow Mottle Virus in the major lowland rice catchment area. Errors bars represent standard error of the means.

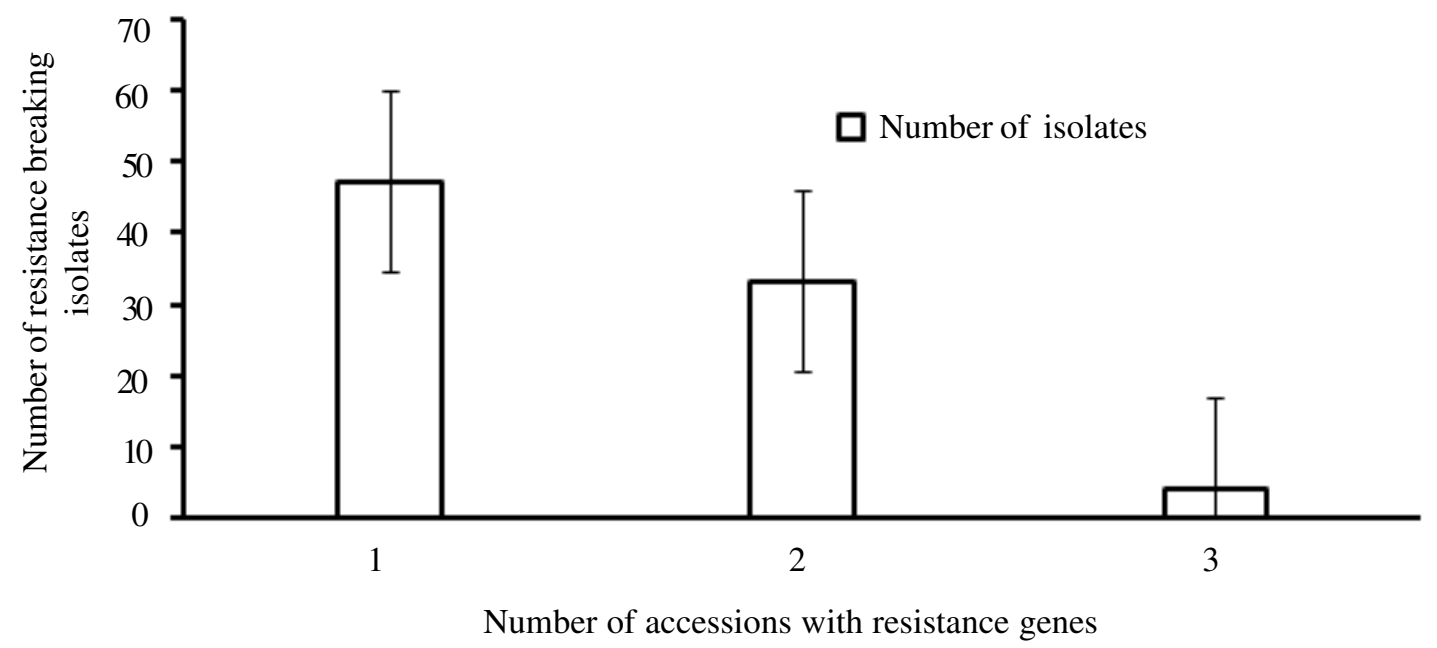

Figure 5. Number of isolates that broke down $R Y M V$ resistance in within selected accessions with resistance genes.

attributed to a number of factors like mutations in the viruses leading to more pathogenic isolates which break down the previously established resistance amongst other factors. The mutations in the viral sequences are mainly due to the fact that most RNA polymerases in viruses are error prone due to lack of proof reading ability. Currently, much effort in the management of RYMV is geared towards the development of tolerant or resistant lines through the utilisation of major genes and quantitative trait loci (QTLs) (Pidon et al., 2017). The fact that Rice yellow mottle virus is a single-stranded positive-sense RNA virus 


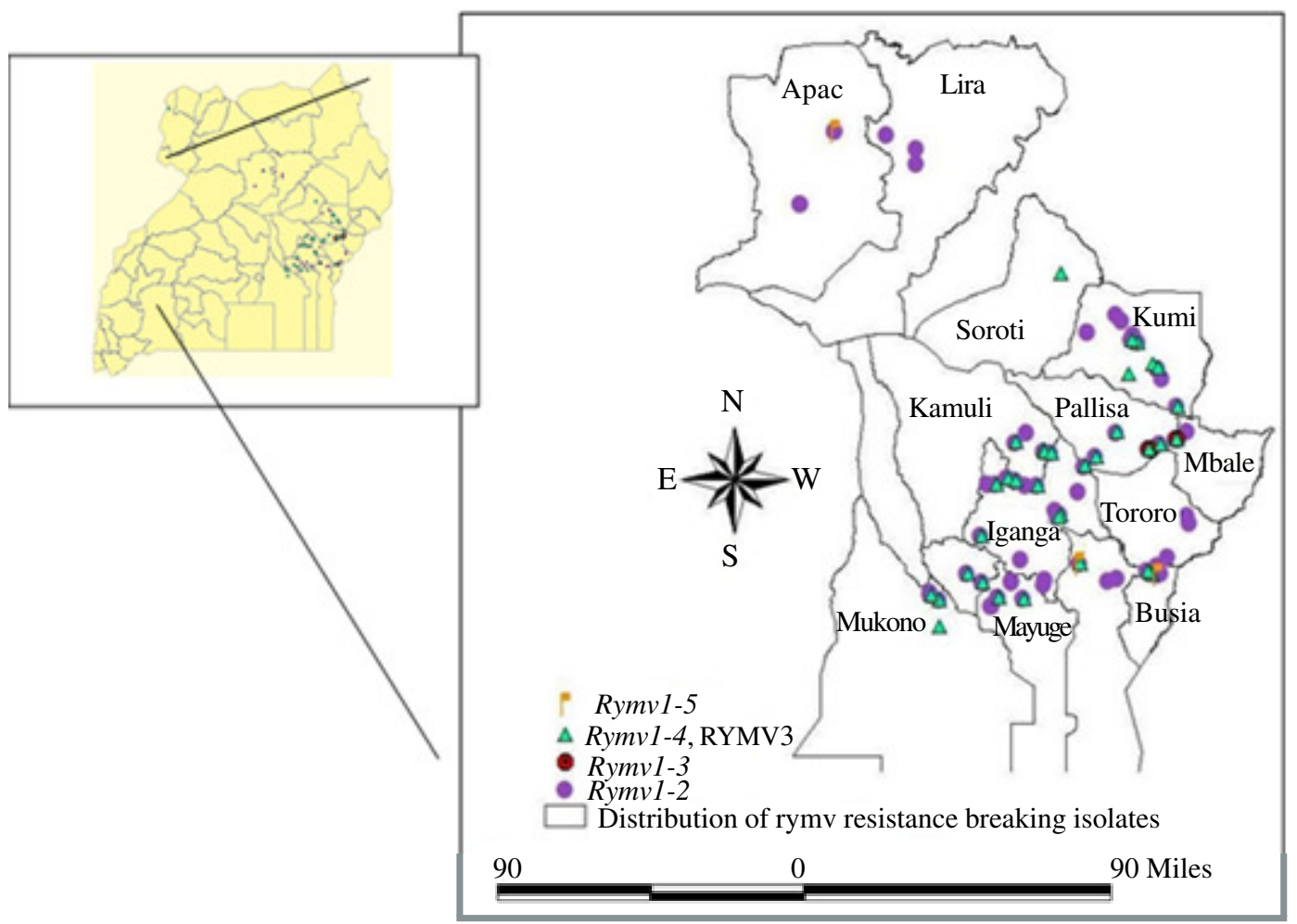

Figure 6. Map of Uganda indicating locations where $R Y M V$ resistance-breaking isolates were collected from.

and with a small genome ( $4450 \pm 2$ nucleotides), it evolves rapidly thus leading to the formation of resistance breaking variants (Kouassi et al., 2005; Fargette et al., 2008). The identification of these variants is an important step in the screening of newly bred resistant lines before they are deployed in the field.

Results in this study indicated that the majority of the RYMV isolates across the three rice catchment zones in Uganda were able to induce symptoms on rice accession Gigante and Tog 5672, contrary to earlier observations on the same accessions in West Africa (N'Guessan et al., 2001). The difference is attributed to the differences in pathogenicity of the RYMV isolates in the different zones. It was reported that T-pathotypes of RYMV are more prevalent in West Africa; while Epathotypes are common in East Africa (Pidon et al., 2020; Odongo et al., 2021). The differences in pathotypes is attributed to mutations that occur within the virus genome for infection to occur.

Gigante (rymv1-2) is an O. sativa cultivar; while Tog 5672 (rymv1-4, RYMV3) is an $O$. glaberrima cultivar. Both express high resistance conferred by the RYMV1 and RYMV3 genes (Albar et al., 2006; Rakotomalala et al., 2008). The RYMV1 gene induces resistance in a recessive way and encodes a eukaryotic translation initiation factor eIF(iso)4G1 (Albar et al., 2006). Two important amino-acid positions (E309 and E321) are involved in RYMV resistance and both undergo substitution mutation of the glutamic acid residue by a lysine residue $(\mathrm{K})$ at position 309 (E309K) for rymv1-2 and 321 (E $321 \mathrm{~K})$, for rymv1-4 allele. The high percentage break down in resistance in Gigante and Tog5672 indicate a possible occurrence of new variants, different from those reported twenty years ago by Pinel-Galzi et al. (2006). 
These variants having undergone mutation at codon 48 of the VPg gene that interacts with the host factor to determine its ability to overcome resistance (Ndjiondjop et al., 2001; Hebrard et al, 2010). The mutations result in the deletion of a threonine (T49) amino acid at codon 48 , a substitution of the threonine for alanine amino acid at position 43 and an exchange of phenylalanine for leucine in polyprotein $\mathrm{P} 2 \mathrm{a}$ ) in order to overcome resistance conferred by the rymvl-2, rymvl4 allele and RYMV3 gene respectively (Traore et al., 2010; Pine-Galzi et al., 2016).

The low number of isolates showing symptoms on Tog5681 and Tog 5674 is attributed to the inability of the majority of the Uganda RYMV isolates to break down resistance conferred by allele's rymv1-3 and rymv1-5 found within the respective accessions. Resistance confirmed by these two alleles is attributed due to a tripeptide deletion at positions 322-324 for rymvl-3 and at positions 313-315 for rymv1-5 (Albar et al., 2006; Thiémélé et al., 2010). The break-down in resistance by some of the isolates is attributed to mutations occurring at codon 41 and 52 by the T-pathotypes with the substitution of threonine amino acid by the alanine (Odongo et al., 2021). These mutations restore the interaction between the central domain of the resistance gene product and the mutated VPg (Hébrard et al., 2010). Furthermore, Tog5681 and Tog5674 are Oryza glaberrima accessions that have their center of origin in West Africa and, thus they have not co-evolved with RYMV isolates in Uganda (Porteres, 1950).

The occurrence of resistance breaking isolates among the Togo lines indicates a possible long distance transmission of $\mathrm{T}$ pathotypes from West Africa to East Africa; or an occurrence of mutants/variants similar to those in West Africa (Ochola et al., 2015). However, the high resistance expressed by rymv1-3 allele indicates that the majority of the Ugandan RYMV isolates possess a glutamic acid (E49) at codon 49, thus referred to as E- pathotypes (Pinel-Galzi et al., 2016). The Epathotypes are polymorphic at codon 48 of $\mathrm{VPg}$, and in avirulent isolates, a conserved arginine occurs in this region; thus the resistance induce by Tog5681 (Kam et al., 2018; Odongo et al., 2021).

The breakdown in resistance in all the four resistant accessions by the Ugandan isolates was similarly observed in Tanzania when isolates collected from Morogoro and Arusha broke down resistance in Gigante and Tog5681, but not on Tog5672. These observations were different from those made earlier on isolates collected in West Africa (N'Guessan et al., 2001; Onasanya et al., 2011; Oludare et al., 2016). The differences could further be attributed to the difference in strains. S1, S2, and S3 strains are predominant in West Africa; while S4, S5, and S6 strains are found in East Africa. The difference in strains is attributed to the differences in the nucleotide and amino acid compositions of the RNA of isolates. These difference accounts for $11 \%$ between the two region (Pinel et al., 2000; Oludare et al., 2016).

There was significant variation in the time for symptoms expression (5 to $36 \mathrm{dpi}$ ). This variation is an important determinant in distinguishing between rice genotypes. Rice varieties with partial resistance usually show a delay in symptom expression and a low virus titer after inoculation, as compared to susceptible lines (IR64 and BG 90-2). The long duration for symptoms expression in Tog5674, Tog5681 and Tog5672 confirm that partial resistance is induced in these accessions as was the case in the Asian rice var. japonica cv. Azucena and Tog5681 in West Africa (Albar et al., 1998; Longue et al., 2018). Furthermore, the differences in time of symptom expression could be attributed to the fitness gain of virulent mutants of Ugandan $R Y M V$ isolates to their adaptability to the Oryza sativa indica species, as compared to the Oryza glaberrima species (Ndjiondjop et al., 2013; Hebrard et al., 2018). 
The area under Disease Progress curve varied significantly from 43.5 to 334.5 among the different accessions due to the different isolates collected across the three catchment zones. The Togo lines had low AUDPC values compared to Gigante and IR64. However, the few isolates that induced disease on Tog5681 and Tog5674 had a maximum AUDPC of 270.5 and 150.0, respectively, despite the long duration (18 to $36 \mathrm{dpi}$ ) taken to express symptoms. The long duration for symptoms expression is explained by the phenomenon of late infection. This phenomenon is reported to be associated with RYMV1 resistance gene that these accessions do express (Hubert et al., 2017). The low AUDPC values in Togo lines is attributed to the resistance gene; while the high value expressed by Gigante and IR64 is due to their susceptibility to RYMV (Kam et al., 2018).

Overall, there was a high frequency of occurrence of resistance-breaking isolates across the three catchment areas in Uganda. Similar observations were made by Traore $e t$ al. (2006) when they noticed that $40 \%$ of the collected isolates in West and Central Africa were able to overcome the high resistance expressed by Gigante (alele rymv 1-2) and Tog5681 (allele rymv1-3). In Chad, resistancebreaking isolates had the lower ability of $7 \%$ to overcome resistance in Gigante compared to those in Cameroon (30\%) and Uganda (92.8\%). In Chad, RYMV isolates could not break resistance in Tog 5681; while in Cameroon, $9 \%$ and $2.4 \%$ in Uganda had the ability to break resistance. The high frequency of resistance breaking isolates indicates an easy adaptation of isolates from East Africa to this RYMV1 gene. Nevertheless, it can be deduced that isolates from East and Central Africa have some level of similarity attributed to their high frequency of RYMV resistance break down on Gigante, as compared to other Tog5681.

Six pathotypes were identified among the 83 RYMV isolates tested on the differential lines. The high number of pathotypes could be due to the fact that there is limited or no horizontal resistance deployed in the field. Majority of the lowland rice accessions preferred by farmers in Uganda, predominately Kaiso, Supa, and NERICA10 (Masette et al., 2013), are susceptible to RYMV (Mogga et al., 2012). By farmers growing these susceptible accessions, no selection pressure is imposed on the occurring pathotype. Furthermore, the high pathotype diversity could be due to the long interaction between the virus and host most especially among the rice irrigation schemes that were established way back in the 1970s (Kibimba - 1976, Doho - 1989 and Olweny -1990) (Namyenya et al., 2014). This interaction favoured the evolution of new variants / pathotypes within the Uganda pathosystem.

Pathotypes breaking down resistance was wide-spread; however, the occurrence of RYMV resistance breaking isolates for rymv13 and rymv $1-5$ was restricted to mainly in Doho (Budaka, Butaleja) and Kibimba (Bugiri district) catchment areas. These areas are at a more epidemic risk, as compared to other localities where these gene/ alleles can be deployed. Doho and Kibimba catchment areas are located in Eastern Uganda close to the Lake Victoria basin, where the first report of RYMV was confirmed in Uganda in 2000 ( Pinel-Galzi et al., 2006); and also closer to Otonglo near Kisumu area along the shore of Kavirondo Gulf of Lake Victoria in western Kenya in 1966 (Bakker, 1970). This means that the RYMV isolates within the Lake Victoria basin have had enough time to co-evolve with the host thus resulting in different strains. The current Ugandan strain (S4ug) is different from the S4iv strain that has been prevalent in the Lake Victoria basin. This strain (S4ug) is closely related at the genomic level to the strain in Madagascar that is located $2000 \mathrm{Kms}$ from the Uganda border (Abubakar et al., 2003; Ochola et al., 2015).

The occurrence of resistance-breaking isolates in the major lowland catchment areas is a major threat to the rice industry in Uganda, as sustainable production cannot be insured 
among the farmers' fields. Furthermore, farmer's practices of retention of crop residues within their fields, further aggravate the problem attributed to increased inoculum load within their fields. Virus inoculum is a key resistance breaking factor that favours the occurrence of several pathotypes as observed in this study (Sorho, 2006).

\section{CONCLUSION}

This study has confirmed the wide-spread occurrence of resistance breaking RYMV isolates, more so on Gigante, a close relative to lowland rice (Oryza sativa) and to the distant accessions of Tog5681, Tog5672 and Tog5674 (O. glaberrima accessions). Based on the time of expression of RYMV symptoms and the AUDPC, Tog5681, and Tog5674 expressed high resistance and, therefore, can be deployed in the field; however, this may not be sustainable for durable management of RYMV in Uganda due to the high number of pathotypes confirmed. This study recommends that representative RYMV isolates from the different categories are tested at the molecular level for their diversity and their reaction to differential lines Tog7291 and Tog5307 carrying the RYMV3 and RYMV2 resistance genes, respectively.

\section{ACKNOWLEDGMENT}

This work was funded by the Uganda government with support from the World Bank, through the East Africa Agricultural Productivity Project (EAAPP), implemented by the National Agricultural Research Organisation (NARO). This was part of the first author Ph.D. research, at College of Agriculture and Environmental Sciences, Makerere University, Kampala, Uganda.

\section{REFERENCES}

Abubakar, Z., Ali, F., Pinel, A., Traoré, O., N'Guessan, P., Notteghem, J. L., Kimmins, F., Konaté, G. and Fargette, D. 2003.
Phylogeography of rice yellow mottle virus in Africa. Journal of General Virology 84:733-743.

Albar, L., Bangratz-Reyser, M., Hebrard, E., Ndjiondjop, M-N., Jones, M. and Ghesquiere, A. 2006. Mutations in the eIF (iso) $4 \mathrm{G}$ translation initiation factor confer high resistance of rice to Rice yellow mottle virus. The Plant Journal 47:417-426.

Albar, L., Lorieux, M., Ahmadi, N., Rimbault, I., Pinel, A., Sy, A., Fargette, D. and Ghesquiere, A. 1998. Genetic basis and mapping of the resistance to Rice yellow mottle virus. I. QTLs identification and relationship between resistance and plant morphology. Theoretical and Applied Genetics 97:1145-1154.

Amancho, N.A., Kouassi, N.K., Diallo, H.A., Bouet, A., Sangare, A. and Kouadio, J.Y. 2009. The report of highly resistancebreaking isolates of Rice yellow mottle virus in Cote d'ivoire. The African Journal of Plant Science and Biotechnology 3(1):4450.

Bakker, W. 1970. Rice yellow mottle virus, a mechanically transmissible virus disease of rice in Kenya. The Netherlands Journal of Plant Pathology 76:53-63.

Birdlife International. 2021. Important bird areas factsheet: Kibimba Rice Scheme. Downloaded from http://www.birdlife. org Accessed on 04/08/2021.

Bwambale, E., Home. P.G., Raude. J.M. and Wanyama, J. 2019. Hydraulic performance evaluation of the water conveyance system of Doho rice irrigation scheme in Uganda. Journal of Sustainable Research in Engineering 5(2):101-112.

Campbell, C.L. and Madden. L.M.1990. Introduction to Plant Disease Epidemiology. New York: John Wiley and Sons.

Fargette, D., Pinel-Galzi, A., Sérémé, D., Lacombe, S., Hébrard, E., Traoré, O. and Konate, G. 2008. Diversification of rice yellow mottle virus and related viruses spans the history of agriculture from the Neolithic to the present. PLoS Pathogen. 
4:e1000125. doi: 10.1371/journal.ppat. 1000125.

Hebrard, E., Pinel-Galzi, A., Oludare, A., Poulicard, N., Aribi, J., Fabre, S., Issaka,S., Mariac, C., Dereeper, A., Albar, L., Silue, D. and Fargette, D. 2018. Identifcation of a hypervirulent pathoyype of Rice yellow mottle virus : A threat to genetic resistance deployment in westcentral Africa. Phytopathology 108(2):299307.

Hebrard, E., Poulicard, N., Gerard, C., Traore, O., Wu, H., Albar, L., Fargette, D., Bessin, Y. and Vignois, F. 2010. Direct interaction between the Rice yellow mottle virus $(R Y M V) \mathrm{VPg}$ and the central Domain of the Rice eIF (iso)4G1 factor correlates with rice susceptibility and $R Y M V$ virulence. Molecular Plant-Microbe Interactions 23(11):1506-1513.

Hubert, J., Herman, J.F.L. and Luzi-Kihupi, A. 2017. Pathogenic variation and occurrence of multiple resistance breaking Rice yellow mottle virus strains in Tanzania. American Journal of Plant Science 8(8): 1820-1841.

International Rice Research Instutite (IRRI), 1988. Standard evualuation system (SES) for rice. Los Banos, Laguna, The Philippines, $3^{\text {rd }}$ Edition. 23pp.

Kam, H., Ndjiondjp, M.N., Ouedraogo, N., Laing, M.D. and Ghesquiere, A. 2018. Evaluation of rice cultivars for resistance to Rice yellow mottle virus. African Crop Science Journal 26(1):49-61.

Koudamiloro, A., Nwilene, F.E., Togola, A. and Akogbeto, M. 2015. Insect vectors of Rice yellow mottle virus. Journal of Insect 721-751.

Kouassi, N.K., N'Guessan, P., Albar, L., Fauquet, C. and Brugidou, C. 2005. Distribution and characterization of Rice yellow mottle virus: A threat to African farmers. Plant Disease 89:124-132.

Kreuze, J.F. and Valkonen, J.P.T. 2017. Utilisation of engineered resistance to viruses in crops of the developing worlds, with emphasis on sub-Saharan Africa. Current opinions in Virology 26:90-97.

Lecog, H., Moury, B., Desbiez, C., Palloix, A. and Pitrat, M. 2004. Durable virus resistance in planta through coventional approach : A challenge. Virus Research 100(1):31-39.

Longue, R.D.S., Traore, V.S.E., Zinga, I., Asante, M., Bouda, Z., Neya, J.B., Barro, N. and Traore, O. 2018. Pathogenicity of Rice yellow mottle virus and screening of rice accessions from the Central African Republic. Virology Journal 15(6). doi.org/ 10.1186/s12985-017-0912-4.

Masette, M., Candia, A., Khakasa, E., Okurut, S. and and Tinyiro, S.E. 2013. Preferences of Ugandan consumers for rice accessions and brands on the local market. Uganda Journal of Agricultural Sciences 14(2):111.

Masek, T., Vopalensky, V., Suchomelova, P. and Pospisek, M. 2005. Denaturing RNA electrophoresis in TAE agarose gels. Analytical Biochemistry 336:46-50.

Mogga, M.L., Lamo, J., Asea, Gibson, P. and Edema, R. 2012. Reaction of rice cutviars to a vrulent Rice yellow mottle virus strain in Uganda. African Crop Sciecne Journal 20(s1):52-57.

N'Guessan, P., Pinel, A., Sy, A. A., Ghesquière, A. and Fargette, D. 2001. Distribution, pathogenicity, and interactions of two strains of Rice yellow mottle virus in forested and savannah zones of West Africa. Plant Disease. 85:59-64.

Namyenya, A., Serunkuma, D. and Bagamba, F. 2014. Willingness to pay for irrigation water and its determinants among rice farmers at Doho Rice irrigation scheme (DRIS) in Uganda. Journal of Developmental and Agricultural Economics 6(8):345-355.

Ndjiondjop, M.N., Albar, L., Fargette, D., Fauquet, C. and Ghesquière, A. 1999. The genetic basis of high resistance to Rice yellow mottle virus (RYMV) in accessions 
of two cultivated rice species. Plant Disease 83:931-935.

Ndjiondjop, M.N., Brugidou, C., Zang, S., Fargette, D., Ghesquiere, A. and Fauquet, C. 2001. High resistance to Rice yellow mottle virus in two cultivated rice cultivars is correlated with failure of cell to cell movement. Physiological and Molecular. Plant Pathology 59:309-316. doi: 10.1006/ pmpp.2001.0368.

Ndjiondjop, M.N., Albar, L., Sow, M., Yao, N., Djedatin, G., Thiémélé, D. and Ghesquière, A. 2013. Realizing Africa's rice promise. Integration of molecular markers in rice improvement: A case study on resistance to Rice yellow mottle virus. CAB International Chapter 12:161-173.

Ochola D., Issaka S., Rakotomalala M., PinelGalzi A., Ndikumana I., Hubert J., Hébrard E., Séré Y., Tusiime G. and Fargette D. 2015. Emergence of Rice yellow mottle virus in eastern Uganda: Recent and singular interplay between strains in East Africa and in Madagascar. Virus Research 195:64-72.

Ochola, D . and Tusiime, G. 2011. Survey on inclidence an severityof Rice yellow mottle virus in Eastern Ugana. International Journal of Plant Pathology 2(1):15-25.

Odongo . P.J., Onaga, G., Ricardo, O., Natsuaki K.T., Alicai, T. and Geuten, K., 2021. Insights into natural genetic resistance to Rice Yellow Mottle Virus and implications on breeding for durable resistance. Frontiers in Plant Science 12:1088. doi=10.3389/fpls.2021.671355.

Oludare, A., Tamwgnon, H., Kossi Kini, T. and Silue, D. 2016. Diversity of Rice yellow mottle virus in Benin and Togo and screening for resistant accessions. Journal of Phyto Pathology 164:924-935.

Onasanya, R.O., Olufolaji, D.B., Onsanya, A., Sere, Y., Nwilene, F.E., Wopereris, M. and Kiepe, P. 2011. Occurrence, distribution and characterisation of Rice yellow mottle virus isolates genus Sobemovirus in Southwest Nigeria. Trends Applied Sciences Research 6:1301-1323.
Pidon, H., Ghesquiere, A., Chéron, S., Issaka, S., Hebrard, E., Sabot, F., Kolade, O. and Silué, D. 2017. Fine mapping of RYMV3: a new resistance gene to Rice yellow mottle virus from Oryza glaberrima. Theoretical Applied Genetics 130:807-818.

Pidon, H., Chéron, S., Ghesquière, A. and Laurence, A. 2020. Allele mining unlocks the identification of RYMV resistance genes and alleles in African cultivated rice. $B M C$ Plant Biology 20(1):222. doi.org/10.1186/ s12870-020-02433-0

Pinel-Galzi, A., Fargette, D. and Hull, R. 2006. First report of Rice yellow mottle virus in Rice in Uganda. Plant Disease 90 (5):683. Pinel-Galzi, A., Dubreuil-Tranchant, C., Hébrard, E., Mariac, C., Ghesquière, A. and Albar, L. 2016. Mutations in Rice yellow mottle virus polyprotein $\mathrm{P} 2 \mathrm{a}$ involved in RYMV2 gene resistance breakdown. Frontiers in Plant Science 7:1779. doi: 10.3389/fpls.2016.01779.

Pinel, A., N'Guessan, P., Bousalem, M. and Fargette, D. 2000. Molecular variability of geographically distinct isolates of Rice yellow mottle virus in Africa. Archives of. Virology. 145: 1621-1638. doi: 10.1007/ s007050070080.

Porteres, R. 1950. Homologous intraspecific articulation and monophyletic origin of Oryza sativa and O.glaberrima. Reviue Botanique Applique Agronomie Tropicale 30:147-157.

Rakotomalala, M., Pinel-Galzi, A., Albar, L., Ghesquière, A., Rabenantoandro, Y., Ramavovololona, P. and Fargette, D. 2008. Resistance to Rice yellow mottle virus in rice germplasm in Madagascar. European Journal Plant Pathology 122:277-286. doi: 10.1007/s10658-008-9282-5.

Sarra, S., and Peters, D. 2003. Rice yellow mottle virus is transmitted by cows, donkeys, and grass rats in irrigated rice crops. Plant Disease 87:804-808.

Sarra, S., Oevering, P. and Peters, D. 2004. Wind-mediated spread of Rice yellow mottle 
virus (RYMV) in irrigated rice crops. Plant Pathology 53:148-153.

Sorho, F. 2006. The yellow variegation of rice $(r y m v)$ in west aArica: phylogeography, pathogeny and durability of natural resistances. PhD thesis, Université de Cocody, Côte d'Ivoire. 137pp.

Steel, R.G.D. Torrie, J.H. and. Dickey, D.A. 1997. Principles and procedures of statistics: A biometrical approach. New York: McGraw-Hill. 633pp.

Thiemele, D., Boisnard, A., Ndjiondjop, M.M., Cheron, S., Sere, Y., Ake, S., Ghesquiere, A. and Albar, L. 2010. Identification of a second major resistance gene to Rice yellow mottle virus, RYMV2, in the African cultivated rice species. glaberrima. Theoretical and Applied Genetics 121:169179. doi: 10.1007/s00122-010-1300-2.

Traoré, O., Pinel-Galzi, A., Issaka, S., Poulicard, N., Aribi, J., Aké, S.,
Ghesquiere, A., Sere, Y., Konate, G., Hebrard, E. and Fargette, D. 2010. The adaptation of Rice yellow mottle virus to the eIF(iso)4G-mediated rice resistance. Virology 408:103-108. doi: 10.1016/ j.virol.2010.09.007.

Traoré, O., Pinel, A., Hebrard, E., Gumedzoe, D., Fargette, D., Traoré, A.S. and Konaté, G. 2006. Occurrence of resistancebreaking isolates of rice yellow mottle virus in West and Central Africa. Plant Disease 90:259-263.

World Bank, 2020. International Development Association Project Appraisal document. Uganda Irrigation for Climate Resilience Project (P163836).Report No: PAD3218.

Zeemeijer, I.M. 2012. Who gets what, when and how? New corporate land acquisitions and the impact on local livelihoods in Uganda. Master, Utrecht. 